\title{
Regulation of Freight Railroads in the Modern Era: 1970 - 2010
}

\author{
DARIUS W. GASKINS, JR. * \\ Partner, Norbridge, Inc.
}

\begin{abstract}
The fundamental tension between the freight railroads' network economics and economic regulation has never been resolved. Lip service has been paid to declining marginal costs and Ramsey pricing, but the actual practice of economic regulation has not coped with the economic dilemma. This paper relates the trials and tribulations of railroad regulation from the perspective of a participant that has seen the struggle both as a regulator and a regulatee.
\end{abstract}

\section{Introduction}

The most important thing I learned from Fred Kahn was that any serious micro-economist should be concerned about the practical consequences of his/her discipline. His role as a practicing regulator inspired me to pursue such a career.

From 1979 until today, I have been involved in one way or another with the regulation of America's freight railroads.

Beginning in the 1970's, there has been a revolution in the way U.S. freight railways are regulated. An industry deemed to be failing economically has been revived by substantial deregulation. The deregulation of America's railroads relied primarily on competition between railroads and among competing transportation modes to govern rates and services.

It is important to note that "deregulation" of the U.S. railroads has not created a textbook competitive industry. Competition between railroads and with other transportation modes has been created, but there are still many monopolistic or duopolistic features in the rail industry. The residual regulatory issue is what the appropriate remedies for "captive" or sole-served rail customers are. Sadly to say, this regulatory dilemma still has not been solved to everyone's satisfaction after 150 years of effort. ${ }^{1}$

The current regulatory regime for U.S. freight railroads was established by the passage of the Railroad Revitalization and Regulatory Reform Act (4R Act) in 1976 and the Staggers Act enacted in 1980. These two statutes were created in response to financial failure of the U.S. railroads in the 1970's. The Penn Central bankruptcy, the bankruptcy of Milwaukee Railroad, and the liquidation of the Rock Island Railroad were the most

\footnotetext{
* Norbridge Inc. 30 Monument Square, Concord, MA, 01742. Email: dgaskins@norbridgeinc.com

${ }^{1}$ This issue was highlighted by Grimm and Winston (2000). Unfortunately, there has been no resolution to date, and rising rail rates have exacerbated the problem.
} 
prominent financial failures. The whole rail industry's return on equity was less than three percent and its return on sales was less than four percent. Much of this poor performance can be attributed to truck competition and poor rail management, but a major contributing factor was the straitjacket of existing railroad regulation.

By 1970, rail rate changes had to be approved by the Interstate Commerce Commission (ICC) (now the Surface Transportation Board). The actual rate proposals were generated by rate bureaus where railroads bargained among themselves with antitrust immunity. Proposed rate increases were frequently blocked or diminished by the ICC. Even rate reductions to compete for traffic subject to modal competition were stymied (Stone, 1991).

The major form of competition between railroads was not price, but market share. The routing of traffic over rail networks was heavily influenced by shipper wishes, not rail economics. Merged railroads were forced to maintain historic (pre-merger) traffic flows by the Detroit, Toledo, and Ironton conditions (DT\&I condition), always applied to any successful merger. In this world, railroad sales people competed for market share through their social interaction with their potential shippers. Rail service mattered, but rail rates were equalized.

This whole regulatory scheme was destroyed with passage and implementation of the Staggers Act. Rate bureaus were prohibited, rates were to be set by individual carriers, confidential contracts between shipper and railroad were not only allowed but encouraged, and strict time schedules were established for approving rail mergers and abandonments. Rates could only be challenged by shippers through processes to be established by the ICC.

A crucial feature of the Staggers Act is that no rate below the jurisdictional threshold of 180 percent of variable rail costs as established by the Uniform Rail Costing System (URCS) may be challenged in a regulatory case by a shipper. The 180 percent threshold was explicitly established by Congress in the recognition that revenue-inadequate railroads must earn more than marginal costs on some traffic to pay for the fixed costs to maintain their networks.

The presumption at the time was that rate freedom would allow railroads to raise most rates and that the 180 percent ceiling would leave enough headroom to allow railroads to earn an adequate return.

The ICC implemented the new legislation aggressively, approving four major rail mergers in the early 1980's. They exempted large chunks of rail traffic from regulation including intermodal traffic, boxcar traffic, and export coal. ${ }^{2}$

\section{Personal journey: The regulatory dilemma}

I began my relationship with rail regulation in the late 1970's as Commissioner and, ultimately, the Chairman of the ICC. My first exposure to the full dimension of the regulatory failure was a hearing before the Commission with prominent Senators and Representatives of the northern-tier states; for example, the Honorable Warren G. Magnuson, Chairman of the Senate Commerce Committee and President Pro Tempore of the Senate, pleading for the ICC to do something to bailout the bankrupt Milwaukee

\footnotetext{
${ }^{2}$ The exemption of export coal was overturned by the courts in 1993 (Chemical Manufacturer's Association, 1993).
} 
Railroad. The answer was that nothing could be done. There were no more appropriated funds to subsidize failing railroads. ${ }^{3}$

The economic dilemma facing the railroads was exacerbated by the reluctance of the regulatory system (the ICC processes) to allow the abandonment of excess and unprofitable operations (Levin, 1981). Falling traffic volumes continuously created an imbalance between revenue and costs.

By 1980, the regulatory regime that served to protect railroads from competition with each other and competing effectively with other transportation modes was not working. A change was necessary, but perhaps not sufficient, to save the railroads.

\subsection{Enter competition}

A second significant episode in my personal journey was a meeting with the railroad presidents at a conference of the American Railroad Association in the spring of 1980. During this session, the railroad executives pleaded to preserve their ability to set rates collectively through rate bureaus immune from the Antitrust Laws. This privilege had already been eroded through the provisions of the 4R Act and its prohibition of antitrust immunity for coordinating rates between rail moves controlled by a single carrier. My response to these pleas was that it was not possible, and that along with reforms to allow greater rate-making freedom and faster decision-making by the ICC we would be relying primarily on competition to protect rail shippers.

Another occasion to articulate the increased reliance on competition between railroads was the Commission's decision to no longer apply the hoary DT\& ${ }^{4}$ conditions to rail mergers going forward. Those conditions attempted to preserve traditional freight patterns from the "competition" of a newly energized, merged rail carrier. When the conditions were first proposed to me in connection with a rail merger in a meeting with the ICC staff, I asked what their purpose was and was told that stable traffic patterns represented "competition" and that we had always done it that way. When the new Commission majority renounced the DT\&I conditions, the railroads all had to amend their pending merger applications to take advantage of the new competitive alternatives, such as increasing their market share when they had the most efficient route.

To conclude this phase of my railroad regulatory education, I must admit that I was convinced along with most other interested parties that the passage of the Staggers Act on the $14^{\text {th }}$ of October 1980 would usher an era of rising rail rates. My belief was based on the fact that the ICC had limited or prohibited proposed rail-rate increases throughout the 1970 's. I remember vividly an argument with another Commissioner who opposed a railrate increase because he believed that the railroads were profitable in spite of the ICC's published data showing an average return of less than three percent.

\footnotetext{
${ }^{3}$ The Federal Government had spent more than $\$ 7$ billion to subsidize Conrail, the successor to the bankrupt Penn-Central. The ICC had further exhausted \$275 million in 1979 - 1980 to keep the Rock Island railroad running, depleting the limited funds appropriated for that kind of directed service.

${ }^{4}$ The DT\&I conditions were first applied in 1950 in the consolidation case Detroit, Toledo \& Ironton R. Co. Control, 275 ICC 455 492. These conditions established a regulatory standard which was only relaxed after 1980.
} 


\section{The denouement}

Figures 1 and 2 tell the story of what competition did to the rail industry. Railroads became much more efficient, and rail rates fell in both nominal and real terms. Rail traffic increased significantly even in the face of a deregulated trucking industry. Increased competition between railroads and with other modes was the most salient cause of this performance. The shocking element of the story is that railroads' new freedom to adjust rates upward was overpowered by the new competitive reality.

In the early years of the Staggers Act, railroad marketing departments had little expertise in rate making. The rail-rate experts wore green eyeshades and worked for the rate bureaus. Railroads had set their rates by negotiating with other railroads. Rail customers were people you played golf with.

There was excess capacity throughout the rail industry, and the initial inclination after the passage of the Staggers Act was to try to fill up one's railroad by cutting rates to attract more volume. The net result was lower rates and some freight moving from intermodal competitors. When in doubt about what rate to establish, the railroad marketing folks often asked their new-found friends - their customers. Strangely enough, the advice seemed always the same - lower rates would be better.

I discovered this world of falling rates in my new job at the Burlington Northern Railroad (BN) in 1982 where I was in charge of marketing and sales for all rail commodities except for coal. My first clue that something was amiss was that every winter the Mississippi River would freeze, and the BN would offer its lowest rates of the year during the winter at the suggestion of our grain customers.

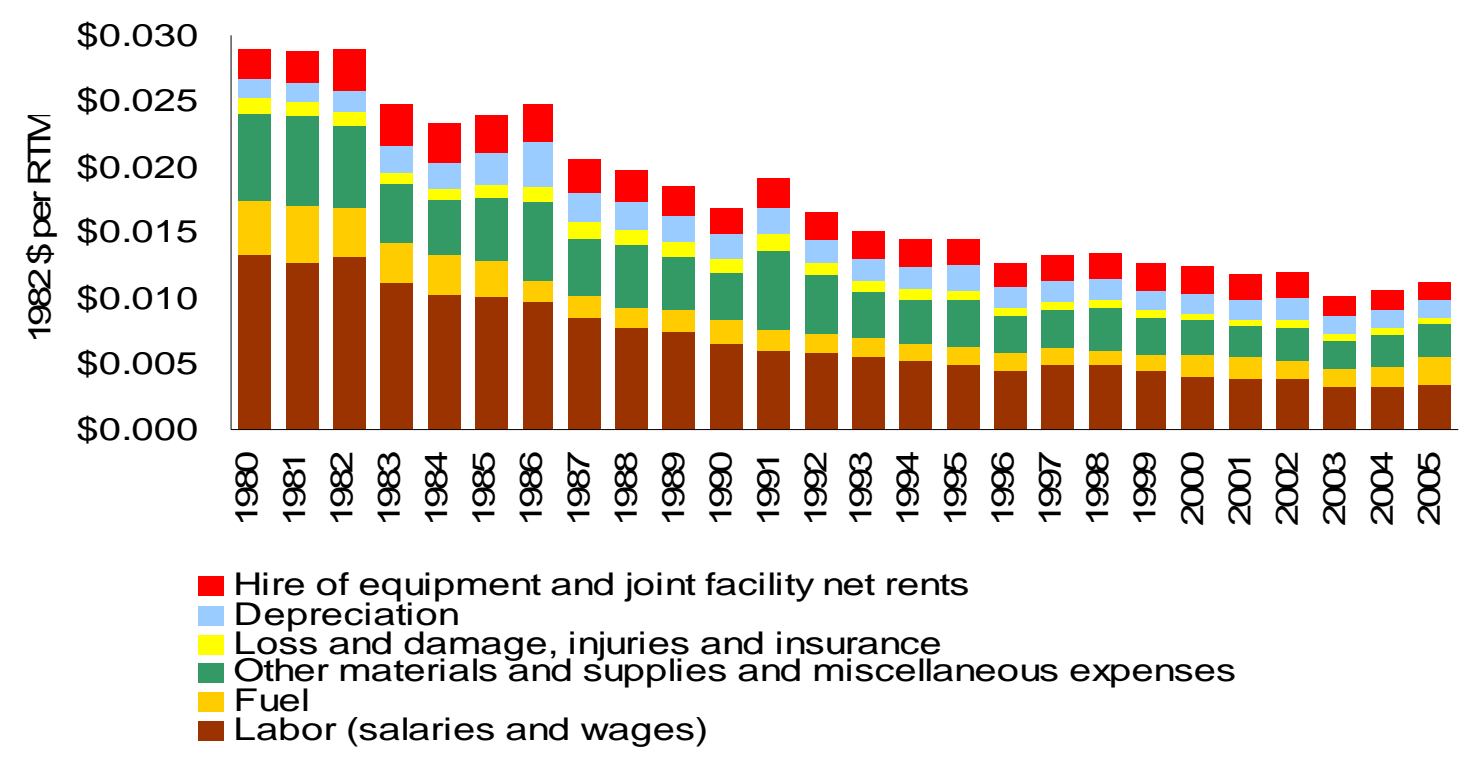

Figure 1: Sustained cost reductions (per Revenue Ton-Mile)in the rail industry: 19802005

Sources: AAR, Norbridge, Inc. 


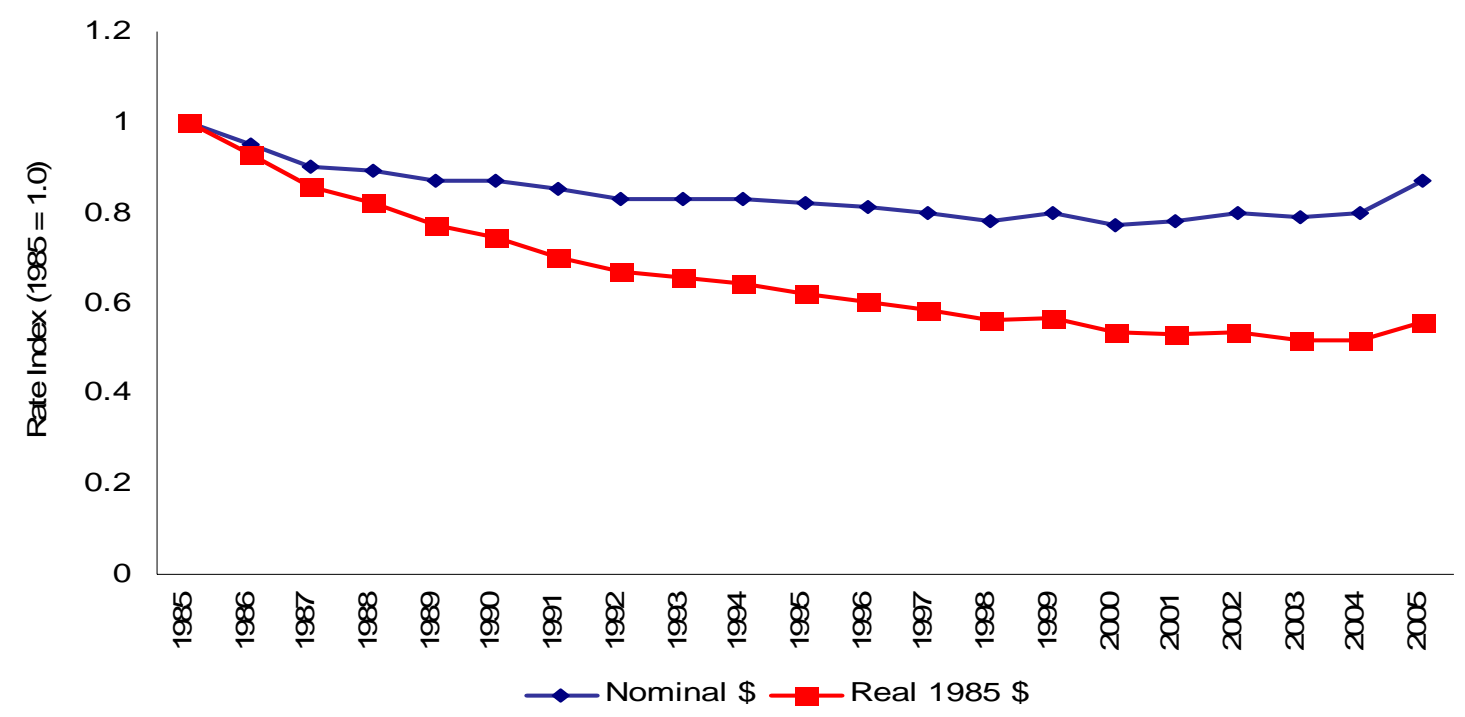

Figure 2: Trends in GAO rail rate indices, all freight traffic: 1985-2005

Sources: GAO, Norbridge, Inc.

\section{$4 \quad$ Adaption}

My solution to falling rail rates was to begin to change the people responsible for setting rail rates. Specifically, we hired a group of savvy grain traders from our customers international grain companies. These traders developed an auction system called COTS (certificates of transportation), which developed market information by selling 40 percent of BN's grain transportation in a forward market. The movement of the prices for these forward contracts informed our grain marketeers far better than a quiet chat in a golf cart. ${ }^{5}$

Coal rates were a much tougher nut to crack. The BN had dug quite a hole for itself with its "missionary" rates (rate levels low enough to develop the nascent market for Powder River Basin (PRB) coal) that were established at the outset of rail transportation of coal from the PRB in the late 1970's. When we began to raise coal rates at the urging of our shareholders, we created a firestorm from our utility customers who had gotten very comfortable with BN's missionary rates. The fact that the railroads were found guilty of conspiring to forestall investment in a coal slurry pipeline from the Powder River Basin did not help matters very much. ${ }^{6}$ The BN lost several rate cases filed with the ICC during this era, but the incipient rise in coal rates was smashed by the competitive entry into the Powder River Basin by the Chicago and North Western Railway/Union Pacific Railroad in 1984. We were able to demonstrate for the ensuing 25 years that two is a large number

\footnotetext{
${ }^{5}$ The railroad offered up to 40 percent of its grain hauling capacity in an auction. The certificate of transportation sold could be subsequently traded among potential grain shippers. The trading results were published on an electronic bulletin board maintained by the railroad. The value of traded certificates presumably moved with the new development in grain markets.

${ }^{6}$ The ETSI (Energy Transportation Systems Inc.) case was decided against the railroads in a directed verdict of guilty by the judge. Such outcomes are generally the result of fairly egregious behavior by the defendants.
} 
when considering rail competition. Figure 3 shows the dramatic influence of PRB coal and rail competition on coal rail rates at the national level.

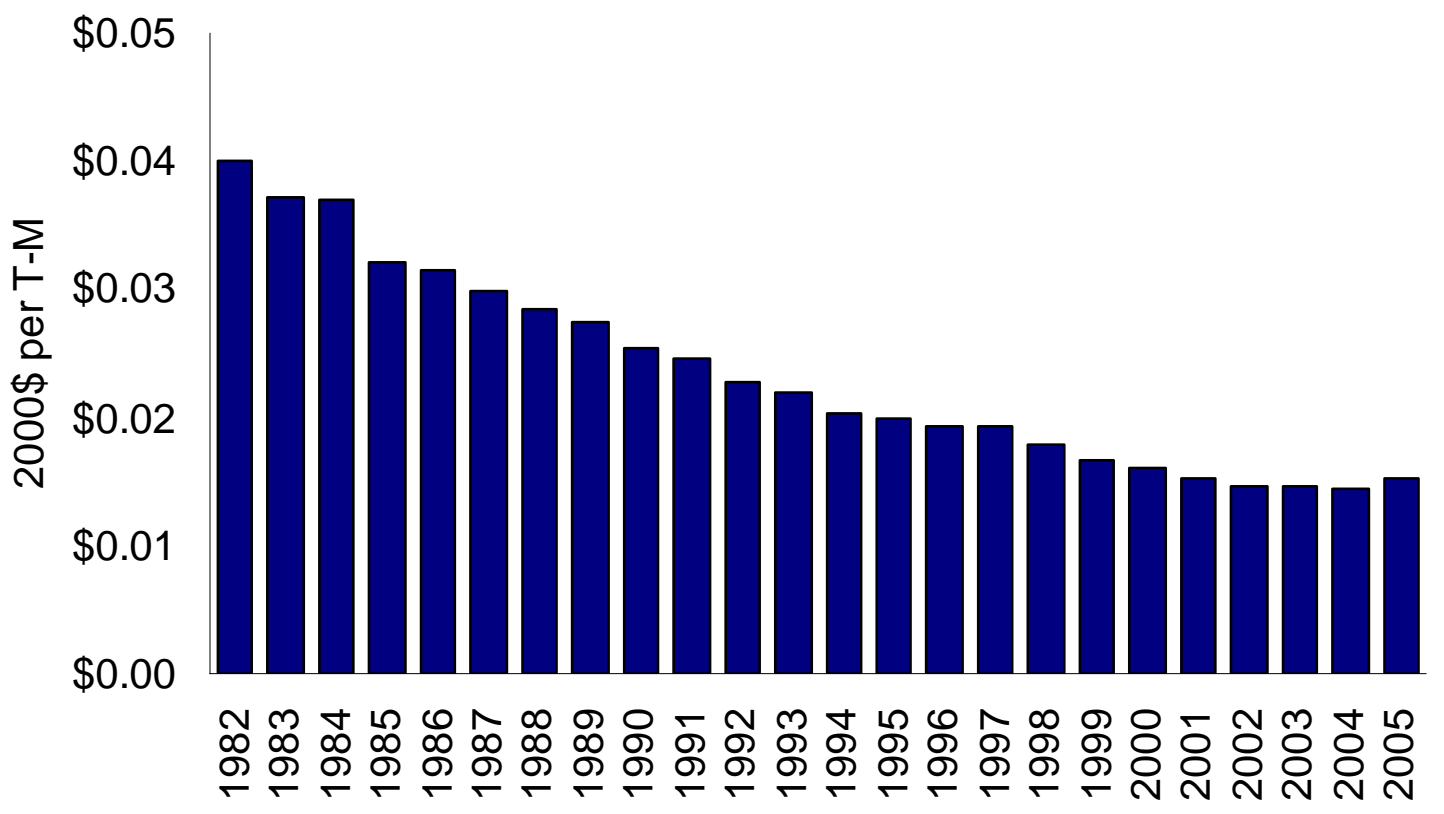

Figure 3: Declining rates for coal delivery: 1982-2005 in 2000 \$ per ton-mile

Source: AAR

\section{$5 \quad$ The economic dilemma}

During the 1980's, the newly created intermodal and intramodal competition drove average rates down from an industry with substantial excess capacity. The railroads had no choice but to dramatically lower costs faster than rates fell. This cost cutting became my primary activity after I became CEO of the BN railroad in 1985. We embarked on a manypronged strategy to lower costs.

First and foremost, we attempted to lower labor costs primarily by reducing the number of employees to operate a train. In 1985, the BN had 5.2 employees per train. This number was gradually reduced to two over a ten-year period. The reduction was extremely difficult because we had to modify our labor contracts to achieve lower manning levels. No labor leader could win re-election if he/she were to concede substantial reductions in manning levels. The changes in the labor contracts were ultimately achieved by Congressional fiat after we had achieved an impasse with our private negotiations. We made several other efforts to lower labor costs outside of labor negotiations. We sold significant portions of our railroad to new operators who were able to attain vastly improved labor contracts by offering essentially new jobs to individual unions.

We created a wholly-owned subsidiary called Winona Bridge which attempted to takeover the operation of newly created intermodal trains crewed by two employees. 
Unfortunately, the courts took a dim view of this endeavor, and we were forced to give up our double-breasted operation (Newkirk and Casavant, 1989).

A second major prong of our drive for profitability was an aggressive program of reducing the scope of our rail network. We did this by outright abandonment of some operations. Abandonment under the Staggers Act was possible but quickly became politically infeasible. This fact became clear to me when Senator Mark Andrews of North Dakota put a rider on an Appropriations Bill which precluded the ICC from spending any money on processing abandonments of North Dakota rail lines.

To overcome the political obstacles to abandonment, we developed a campaign to sell segments of our network to locally based entrepreneurs who could achieve lower costs than Class I railroads. In every case, the new short lines were bound to our network through contracts which kept the benefit of their feeder traffic for our system. A very low lease payment was the inducement to make these deals possible. The BN had great success with these short-line sales which reduced costs of overall operations and actually grew the associated rail business. A by-product of the short-line rail sales was that the locally based operators often proved to be powerful advocates for the network's interest. ${ }^{7}$

A third prong of BN's cost reduction was to seek assistance from the Federal Government to reduce our retirement and worker's compensation costs by reforming both the Railway Retirement and the Federal Employer Liability Act (FELA). The railroad retirement system was in dire straits with the number of retired rail workers being more than a third of the number of current employees paying into the Social Security type system, which paid benefits significantly more generous than Social Security. FELA encouraged litigation and was much more expensive than normal worker compensation systems covering the rest of the economy.

In addition to these initiatives, the railroad pursued cost reductions and productivity increases across the board. We dramatically increased the life of our track by rail grinding and lubricating curves and the use of concrete ties and better track subsurface maintenance. We eliminated health benefits for retirees. This was one of my wife's favourite actions topped only by our move of the railroad headquarters to Fort Worth, Texas. We changed the way we bought locomotives to provide incentives for the manufacturers to worry about life-cycle costs of tractive power.

Unfortunately, the cost-reduction campaign came agonizingly slowly to fruition and the railroad's owners continued to view the railroad as a poor future investment. BN was governed by a holding company which saw better prospective financial returns through investments in energy, real estate, and natural resources. A substantial portion of the railroad's cash flow was diverted during the 1980's to non-railroad activities. There was no corporate appetite for large, new investments in railroad operations. Essential rail investments were covered by taking on additional debt secured by railroad assets.

During most of the 1980's, the railroad budgeting process was a disaster in that individual projects seemed to be justified on the basis of expected incremental returns, but the full cost of the whole BN network could not be recovered from projected revenues. Slowly, the picture improved as additional cost reductions kicked in. By the time I left the

\footnotetext{
${ }^{7}$ I remember a meeting with the Governor of Montana in 1988 (Ted Schwinden) who was very annoyed with our rail operations in his state. When I told him that we were going to sell almost half of our Montana operation to Denny Washington, a prominent Montana businessman, the blood drained out of the Governor's face. It was no fun to beat up on Denny Washington.
} 
railroad in 1989, the outlook had improved enough to support a spin-off of the railroad with its debts into a separate, publicly traded company.

\section{Residual regulation}

The most frustrating period of my association in the rail industry occurred in the last ten years when I participated as an expert witness in various regulatory proceedings before the Surface Transportation Board (STB), the agency which has residual regulatory responsibility for railroads. The bulk of my activities were in rate cases involving the rail movement of steam coal to utility customers. In this role, I was exposed to the actual practice of regulatory oversight.

The theory of rate regulation of a network with declining costs is dominated by Frank Ramsey's (1927) theoretical work which demonstrated that economic welfare associated with a regulated network is maximized by charging more of the central costs of the network to those customers who value it the most (they have the most inelastic demand). The ICC (1985) paid lip service to this theory in its Coal Rate Guidelines proceedings. Moreover, the Commission always referred to the need of the railroads to earn an adequate return on invested capital. Notwithstanding the reference to Ramsey pricing in theory, the Commission and its successor agency has proceeded to adopt a methodology which by its very nature fails to reflect the revenue needs of any whole railroad network.

The Stand Alone Competitors' (SAC) methodology used to judge the reasonableness of rail coal rates bases the decision on a comparison of a virtual rail network that is constructed to serve the complainant plants while sharing the benefits of other traffic hypothesized to flow over the virtual network. These hypothesized networks or SACs are never defined to cover all of any existing railroad. It is not possible that decisions based on some subsystem of existing networks will provide adequate returns on the whole network. The complainant always tries to include the most remunerative existing traffic in its virtual network.

This flawed intellectual process is mitigated by two significant factors. One, the cost of bringing a case is quite high - in the low seven figures. This fact deters most shippers from bringing a case, and, in fact, cases have been filed only by coal-burning utilities and largevolume receivers of soda ash. The second important mitigation factor is that the statute prohibits driving any rate below the statutory limit of 180 percent of the variable cost of the movement. There is still plenty to argue about, but there have been few complaints filed and fewer cases which involved significant rate reductions.

What is most galling to me personally is that recently the STB has ignored any reference to Ramsey principles. Specifically, one recent coal rate case involved coal transport to a "merchant” power plant (Surface Transportation Board, 2004). In this situation, the marginal cost of power from the coal-burning plant was always well below the marginal price of electricity in the relevant market. The demand elasticity of this merchant's plant was zero (that is, there would be no economic loss if its selling price increased). In other words, this rail rate could be increased substantially without causing an economic welfare loss. Economic rent would go from the highly profitable merchant plant 
to the revenue-inadequate railroad. ${ }^{8}$ The point is that the STB's rate making process deliberately ignores any consideration of demand elasticity, turning its back to any application of Ramsey principles.

\section{$7 \quad$ The worm turns}

As shown in Figures 1 and 2, in recent years the economic conditions in the freight railroad industry have changed dramatically. Excess capacity has been eliminated, and rail rates have begun to rise. Being a buyer of rail services has become a lot less pleasant for shippers. These rate increases have been exacerbated by a clumsy attempt by the railroads to compensate for dramatically rising fuel prices. ${ }^{9}$

Along with rising rail rates, the economic profit of the railroads has increased dramatically in recent years. Perhaps the most telling sign of the rail renaissance is that Warren Buffet, that highly successful investor, has purchased 18 percent of Burlington Northern Santa Fe's stock.

The rise in rail rates in recent years has produced the predictable response from regulators and shippers. The STB has established a new, lower standard for the allowed return on equity. The STB, moreover, has promulgated new standards for judging complaints brought by shippers with smaller volumes of freight.

The plea from shippers for re-regulation of railroads has risen precipitously. Calls have been made for competitive access for all shippers served by single railroads, elimination of the contractual commitments that tie short-line traffic to their historic partner and to mandate "reciprocal switching" of the transfer of traffic from one railroad to another to provide competitive rail service. ${ }^{10}$ The net effect of the proposed legislation would be to eliminate those factors which are perceived to have allowed rail rates for some sole-served shipper to be greater than 180 percent of variable costs.

Barring new legislation, the political pressure for lower rail rates may well drive the STB to reduce rail rates in the near future. Most, if not all, Class I railroads may be deemed to be revenue adequate. Certain traffic exempt from regulation may be drawn back into the net of regulation. The new rate case methodology for small volume shipments proposed by the STB may result in repayments by the railroads of up to $\$ 1$ million per complaint.

\footnotetext{
${ }^{8}$ Surface Transportation Board. STB Docket No. 42054. PPL Montana, LLC v. The Burlington Northern and Santa Fe Railway Company. August 30, 2004. The marginal cost of the Corette plant was extremely low compared to available market prices for wholesale electricity. For example:

Corette Plant Marginal Cost: $\quad \$ 11.15$ (2005) \$8.75 (2006)

Marginal Price in MT/WY: $\quad \$ 14.98(2005) \quad \$ 13.04(2006)$

Marginal Price in WECC: $\quad \$ 53.32$ (2005) $\quad \$ 61.97$ (2006)

The prices are based on an Electricity Dispatch Model (Norbridge, Inc. 2007) based on Energy Velocity data from 2002 to 2006. WECC = Western Electricity Coordinating Council, an electricity dispatch area covering the Rocky Mountains to the West coast of the US.

${ }^{9}$ The railroads' response to dramatically higher diesel prices was to attach a fuel surcharge to shippers' bills which was a percentage of revenue received. This meant that the shippers paying the highest rates before the surcharge received the biggest fuel surcharge. The fact that this was administratively easy did not quell shipper outrage.

${ }^{10}$ The STB and the ICC had previously imposed reciprocal switching arrangements to remedy the potential anticompetitive effect of rail mergers but never to proactively generate rail competition where it never existed.
} 
Certainly the perception of the financial condition of America's freight railroads has changed dramatically.

Table 1 below shows that after operating nearly three decades under the Staggers Act there are many rail freight moves that yield more than 180 percent of variable costs. There is still plenty to fight about without any adjustment of the jurisdictional threshold.

\begin{tabular}{|l|l|rr|l|l|}
\hline STCC & Commodity & \multicolumn{2}{|l|}{$\begin{array}{l}\text { Total revenue } \\
\text { for moves above } \\
\text { R/VC 180\% }\end{array}$} & $\begin{array}{l}\text { Revenue lost if rates } \\
\text { limited to 180\% of } \\
\text { variable cost }\end{array}$ \\
\hline \multicolumn{2}{|l|}{} & \multicolumn{4}{|c|}{ Dollars in thousands } \\
\hline 01 & Farm Products & $\$$ & $1,095,276$ & $\$$ & 489,839 \\
\hline 10 & Metallic Ores & $\$$ & 246,270 & $\$$ & 95,126 \\
\hline 11 & Coal & $\$$ & $3,604,187$ & $\$$ & $2,056,539$ \\
\hline 14 & Nonmetallic Minerals & $\$$ & 386,074 & $\$$ & 180,681 \\
\hline 20 & Food and Kindred Products & $\$$ & 459,741 & $\$$ & 232,056 \\
\hline 24 & Lumber \& Wood Products & $\$$ & 219,660 & $\$$ & 107,900 \\
\hline 26 & Pulp \& Paper Products & $\$$ & 234,172 & $\$$ & 114,831 \\
\hline 28 & Chemicals & $\$$ & $2,622,913$ & $\$$ & $1,312,921$ \\
\hline 29 & Petroleum and Coal Products & $\$$ & 665,783 & $\$$ & 337,650 \\
\hline 32 & Stone, Clay, \& Glass Products & $\$$ & 550,990 & $\$$ & 235,517 \\
\hline 33 & Primary Metal Products & $\$$ & 324,970 & $\$$ & 152,715 \\
\hline 37 & Transportation Equipment & $\$$ & 506,313 & $\$$ & 261,149 \\
\hline & All Other & $\$$ & $2,278,579$ & $\$$ & $1,195,303$ \\
\hline & Total & $\mathbf{1 3 , 1 9 4 , 9 2 8}$ & $\$$ & $\mathbf{6 , 7 7 2 , 2 2 7}$ \\
\hline
\end{tabular}

Table 1: Rail traffic moving with rates above $180 \% \mathrm{R} / \mathrm{VC}$

Note: Revenue and costs from 2004 STB Public Waybill. The Public Waybill revenues are masked by the STB. To control for this, the revenues are adjusted by a factor based on the ratio of masked revenues to real revenues by 2-digit STCC as published in STB EP-646 (Sub-No. 1), 26 July, 2006. Sources: AAR, Norbridge, Inc.

We have an intriguing equilibrium at present. A railroad industry which contains significant market imperfections from a textbook perspective is regulated by practices which vary substantially from their theoretical origins. This situation was tolerable when competition sufficed to drive prices down, but is hotly contested in an era of rising fuel prices and capacity constraints driving prices up.

Recent STB decisions show some indication of a gradual tilt towards shippers' concerns, and it is not clear that the current regulatory process can prevail in an inflationary environment. If, for example, regulatory policy were to drive all rates to the statutory threshold of 180 percent of costs, the railroads' profits would fall by nearly $\$ 7$ billion, a sum which exceeded the Class I railroads' annual earnings and capital expenditures as shown in Table 2 below. 


\begin{tabular}{|l|rr|rr|l|}
\hline & \multicolumn{4}{|c|}{ Dollars in Thousands } \\
\hline Railroad & $\begin{array}{l}\text { Capital } \\
\text { Expenditures }\end{array}$ & \multicolumn{2}{|l|}{$\begin{array}{l}\text { Net operating } \\
\text { income }\end{array}$} & $\begin{array}{l}\text { Capital expenditures as a } \\
\text { percentage of net } \\
\text { operating income }\end{array}$ \\
\hline BNSF & $\$$ & $1,929,347$ & $\$$ & $1,776,296$ & $108.6 \%$ \\
\hline CSX & $\$$ & 877,299 & $\$$ & 816,166 & $107.5 \%$ \\
\hline KCS & $\$$ & 115,993 & $\$$ & 66,995 & $173.1 \%$ \\
\hline NS & $\$$ & 813,171 & $\$$ & $1,607,800$ & $50.6 \%$ \\
\hline UP & $\$$ & $2,165,817$ & $\$$ & $1,279,314$ & $169.3 \%$ \\
\hline GTC & $\$$ & 393,745 & $\$$ & 446,510 & $88.2 \%$ \\
\hline SOO & $\$$ & 94,760 & $\$$ & 82,199 & $115.3 \%$ \\
\hline Total & $\$$ & $\mathbf{6 , 3 9 0 , 1 3 2}$ & $\mathbf{\$}$ & $\mathbf{6 , 0 7 5 , 2 8 0}$ & $\mathbf{1 0 5 . 2 \%}$ \\
\hline
\end{tabular}

Table 2: Capital expenditures and net income for Class I railroads: 2005

Sources: AAR, Norbridge, Inc.

To conclude, I would judge the reform of rail regulation over the last thirty years to be an enormous success. We are left with an untidy process but excellent economic results. After falling from 56 percent to 37 percent in the 30-year period prior to 1980, rail market share, measured in ton-miles, increased to 40 percent between 1980 and 2005 (Association of American Railroads, 1992, 1996, 2006) and the railroads are financially robust. I am reminded of Winston Churchill's thought about democracy - that our regulation of freight railroads is the worst possible process except for all the other known alternatives.

\section{$8 \quad$ References}

Association of American Railroads (1992) “Ten Year Trends: 1982-1991” December.

Association of American Railroads (1996) “Ten Year Trends: 1986-1995” December.

Association of American Railroads (2006) “Ten Year Trends: 1996-2005” December.

Chemical Manufacturer's Association (1993) "Comments on May 7, 1993 in Coal Exporters Association of the United States, Inc. et al. v. United States et al.” 745 F.2d 76, (D.C. Cir. 1984). May 7.

Grimm, Curtis and Clifford Winston (2000) "Competition in the Deregulated Railroad Industry,” in S. Peltzman \& C. Winston (ed.), Deregulation of Network Industries, AEI Brookings: Washington, DC.

Interstate Commerce Commission (1985) ICC Reports, Coal Rate Guidelines, Nationwide, Ex Parte No. 347 (Sub-No. 1), August 8.

Levin, Richard (1981) "Regulation, Barriers to Exit, and the Investment Behaviour of Railroads,” in G. Fromm (ed.), Studies in Public Regulation, 181-224, MIT Press: Cambridge. 
Newkirk, Jonathan and Kenneth Casavant (1989) “Coming Transportation Issues," Agribusiness Newsletter.

Ramsey, Frank P. (1927) “A Contribution to the Theory of Taxation,” Economic Journal, 37: 47-61

Stone, Richard (1991) The Interstate Commerce Commission and the Railroad Industry: A History of Regulatory Policy. Praeger: New York.

Surface Transportation Board (2004) PPL Montana, LLC v. The Burlington Northern and Santa Fe Railway Company, STB Docket No. 42054, August 30. 